\title{
Fuller Rose Beetle, Pantomorus cervinus (Boheman) (Insecta: Coleoptera: Curculionidae) ${ }^{1}$
}

Jamba Gyeltshen and Amanda Hodges ${ }^{2}$

\section{Introduction}

The Fuller rose beetle (FRB), Pantomorus cervinus (Boheman), sometime known as the Fuller rose weevil or Fuller's rose weevil, caused considerable damage to winter rose when it was first reported in the United States from California in 1979 (Chadwick 1965). Damage was also reported on other ornamentals plants including camellias, geraniums, primroses, carnations, dracaenas, azaleas, cissus, begonias, lilies, and horticultural crops such as citrus, persimmon, apple, peach, plum, apricot, strawberry, raspberry, and blackberry (Chadwick 1965).

In the United States, FRB became an issue in 1985 when Japanese quarantine inspectors detected FRB eggs on citrus fruits imported from California (Haney et al. 1987). Following this event, restrictions were imposed and detection of any viable eggs on the fruits led to mandatory fumigation of the entire shipment.

The methyl bromide fumigation treatments resulted in increased costs and fruit damage, particularly for lemons. This stimulated research on

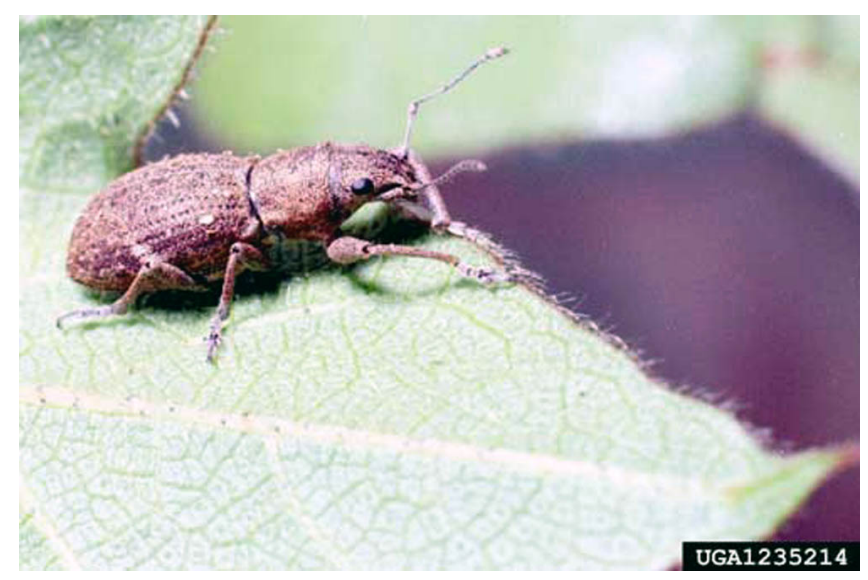

Figure 1. Adult Fuller rose beetle, Pantomorus cervinus (Boheman), on cotton leaf. Credits: Clemson University; www. Insectimages.org

gamma radiation as alternative quarantine treatment (Johnson et al. 1990). Simultaneously, field studies on ovipositional preferences were carried out to gain a better understanding of the biology and ecology in order to develop improved integrated pest management strategies (Coats and McCoy 1990). FRB has recently been removed from the Japanese quarantine pest list (Anonymous 2006) and it would now appear to be less important as a quarantine pest, but it is potentially very damaging to many other plants of ornamental value and economic importance.

1. This document is EENY-375 (IN678), one of a series of Featured Creatures from the Entomology and Nematology Department, Florida Cooperative Extension Service, Institute of Food and Agricultural Sciences, University of Florida. Published: May 2006. This document is also available on Featured Creatures Website at http://creatures.ifas.ufl.edu. Please visit the EDIS Website at http://edis.ifas.ufl.edu.

2. Jamba Gyeltshen and Amanda Hodges, Department of Entomology and Nematology, University of Florida, Gainesville, FL 32611.

The Institute of Food and Agricultural Sciences (IFAS) is an Equal Opportunity Institution authorized to provide research, educational information and other services only to individuals and institutions that function with non-discrimination with respect to race, creed, color, religion, age, disability, sex, sexual orientation, marital status, national origin, political opinions or affiliations. U.S. Department of Agriculture, Cooperative Extension Service, University of Florida, IFAS, Florida A. \& M. University Cooperative Extension Program, and Boards of County Commissioners Cooperating. Larry Arrington, Dean 


\section{Synonymy}

Woodruff and Bullock (1979) lists the following as synonyms of Pantomorus cervinus Boheman:

Pantomorus cervinus (Boheman), Kuschel 1949

Asynonychus cervinus (Boheman), Hustache 1947

Pantomorus olindae Perkins 1900

Naupactus simplex Pascoe 1881

Aramigus fulleri Horn 1876

Asynonychus godmanni Crotch 1867

Naupactus cervinus Boheman 1840

The species A. godmani, A. fulleri, P. olindae were synonymized with Asynonychus cervinus by Hustache in 1947 and 1955, and N. simplex was added to the list by Kuschel (Chadwick 1965).

\section{Distribution}

FRB is generally a cosmopolitan species found widely distributed in North and South America, Europe, the Mediterranean countries, south Africa, Australia and many Pacific islands (see world distribution map).

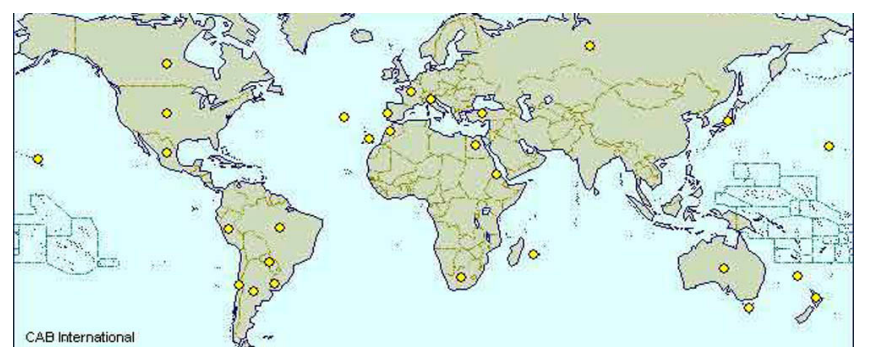

Figure 2. World distribution of the Fuller rose beetle (FRB), Pantomorus cervinus (Boheman), as of 2005. Credits: CAB International

In the United States, FRB is present in at least 30 states (CABI 2005) with the first record from California in 1879 (Chadwick 1965) and Florida in 1916 (Futch and McCoy 1993). There is some evidence that the FRB may have originated in South America (Normack 1996).

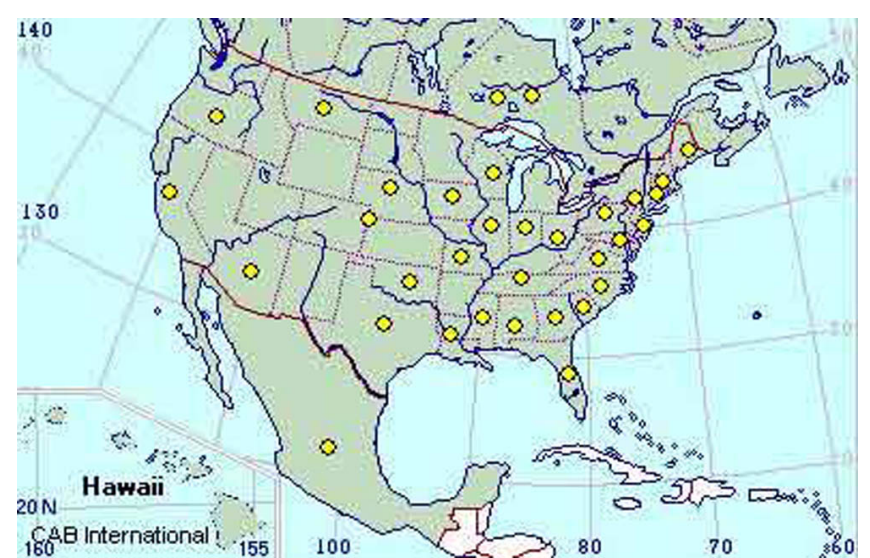

Figure 3. Known Fuller rose beetle distribution in North America. Credits: CAB International

\section{Description}

The description of the life stages is mainly based on Woodruff and Bullock (1979).

Adult: The brownish grey (with intermixed white scales) adults are 6 to $8.5 \mathrm{~mm}$ long ( 1/3 inch). Eyes are in lateral position and appear bulging; rostrum (snout) is slightly curved towards the ground. As the elytra (wing covers) are fused, the insect cannot fly.

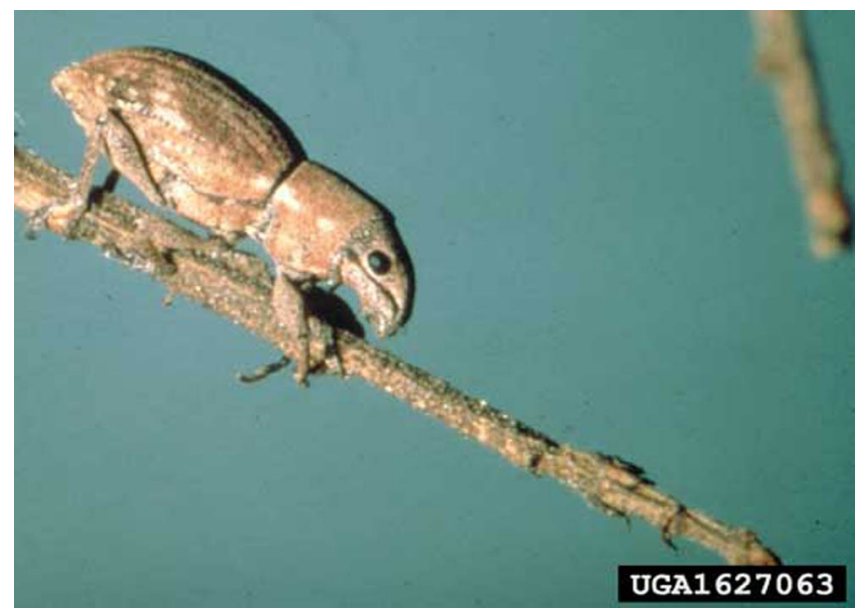

Figure 4. Lateral view of adult Fuller rose beetle, Pantomorus cervinus (Boheman). Credits: Eric R. Day, Virginia Polytechnic Institute and State University; www.insectimages.org

Egg: The yellowish cylindrical eggs, $1 \mathrm{~mm} \mathrm{(1/25}$ inch) long, are laid in a mass and covered with a white sticky material. They are placed in cracks and crevices of bark, between leaves, and under fruit calyces. 


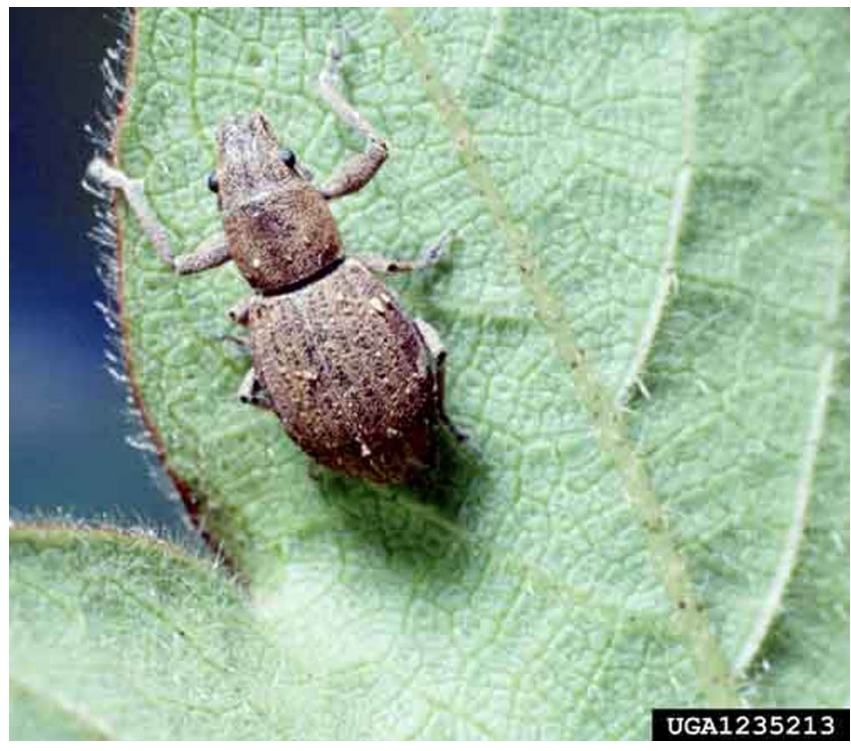

Figure 5. Dorsal view of adult Fuller rose beetle, Pantomorus cervinus (Boheman). Credits: Clemson University; www.insectimages.org

Larva: The white larva, which is legless, has a yellowish head capsule with contrasting black mandibles. When fully grown, it measures 10 to 12 $\mathrm{mm}$ (nearly $1 / 2$ inch) in length.

\section{Biology}

The FRB generally overwinters as larvae in the soil, but in Florida, adults have been collected almost year round and two generations per year have been reported (Woodruff and Bullock 1979, King 1958). Only females are known for this species, and reproduction occurs without fertilization, a phenomenon known as parthenogenesis (Chadwick 1965).

The female lays eggs in a mass and covers them with a white sticky material. In general, eggs are typically stuck under stones, in bark crevices, inside calyx lobes of fruits, or in curled dead leaves (CABI 2005). In citrus, Coats and McCoy (1990) noted that FRB preferred to lay eggs on fruits (83\%) than on leaves $(16 \%)$ or branches $(1 \%)$.

On citrus fruits, eggs are deposited beneath the calyx, and on rare occasions on the navel. Within an egg laying period of three to five months, an adult female lays more than 200 eggs (Woodruff and Bullock 1979). Up to 1000 eggs have been reported as laid by an adult female during its lifetime (Masaki et al. 1996). It takes from two to six weeks for eggs to hatch, depending upon temperature (Lakin and Morse 1989).

After hatching, the legless larva drops to the ground, enters the soil, and feeds on the roots for the next eight to ten months if there is only a single generation. The larva is active to a depth of $61 \mathrm{~cm} \mathrm{(2}$ feet) but the third instar larva moves closer to the soil surface to prepare a smooth walled earthen cell prior to pupation. The larva rotates its abdomen and produces anal secretions that line the walls of the cell. The pupal stage lasts for one and half to two months. Adults emerge and crawl up to their host plant to feed on the leaves, buds or flowers (roses). In Florida, the first peak of emergence is from late May to early June and the second peak is from late August to early September (King 1958). Adults live for three to eight months (Masaki et al. 1996).

\section{Host Plants}

The number of host plants for FRB is very extensive, but the primary hosts include Citrus spp., Cucurbita spp., strawberry (Fragaria ananassa), beans (Phaseolus spp.), peach (Prunus persica), rhubarb (Rheum hybridum), rose (Rosa spp.), and potato (Solanum tuberosum).

Secondary hosts include wattles (Acacia spp.), oriental persimmon (Diaspyros kaki), walnut (Juglans regia), apple (Malus pumila), banana (Musa spp.), passionfruit (Passiflora edulis), avocado (Persea americana), central China wood oil tree (Vernicia fordii) (Anonymous 2005).

Some other economically important hosts of the adult include apricot (Prunus americana), azalea (Rhododendron spp.), Begonia, blackberry and raspberry (Rubus spp.), Gardenia, Hibiscus, Hydrangea, lily (Lilium spp.), oak (Quercus spp.), plum (Prunus domestica) (Anonymous 1996).

\section{Damage}

FRB adults and larvae cause damage. Adults feed on the foliage while the larvae feed on the roots. In citrus, adults feed on young shoots or new foliage at night and remain under shelter during the day. Leaf damage symptoms typically consist of notched or serrated edges with a ragged appearance. Under 
severe infestations, these weevils can consume the entire leaf, leaving only the midrib.

Young larvae chew off the root hairs or rootlets, while older larvae girdle the lateral roots. Root damage results in poor and stunted growth as damaged roots cannot absorb water and nutrients efficiently. Plants with severely damaged roots may die during periods of drought or the root system may be predisposed to fungal infection (Phytopthora spp.).

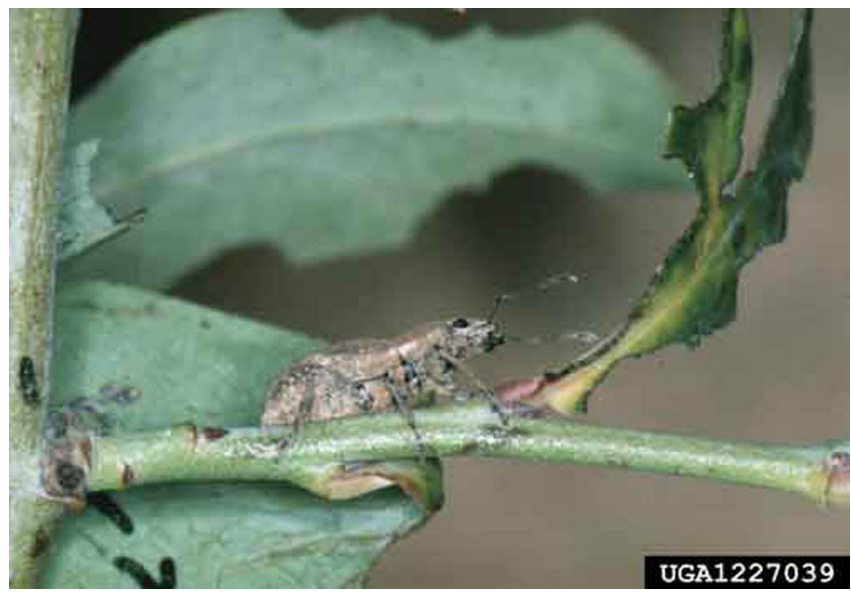

Figure 6. Leaf damage (background and upper right) by adult Fuller rose beetle, Pantomorus cervinus (Boheman). Notice the characteristic dark fecal material (lower left) adults leave on uneaten foliage. Credits: Jerry A. Payne, USDA; www. Insectimages.org

\section{Management}

An integrated pest management approach lays emphasis on monitoring the emergence of a pest population and assessing the amount of damage before making any decision on method and means of control. This is very much applicable to FRB adults management which generally have certain peak period. For FRB, April and May have been the peak emergence period (McCoy et al. 2006).

Monitoring: FRB emergence can be monitored by using ground traps or observing fresh leaf damage. Routine inspection of plants is necessary to check for damage symptoms (ragged appearance) on low hanging foliage. Low-hanging fruits near the trunk should be examined for egg masses, particularly under the calyx. In ornamental shrubs, the presence of adult weevils can also checked by beating the shrub and collecting them as they drop. As FRB are nocturnal in habit, they may not be active during the day and are therefore not very apparent.
Mechanical control: Preventing the flightless weevils from reaching the canopy is the best management strategy. Low lying branches of citrus touching the ground facilitate movement of FRB adults to the canopy. By skirt pruning, the emerging adult weevils can only climb up on the tree trunk. The main trunk thus needs to be treated (banded) with long-lasting sticky materials for trapping the adults. The sticky material is best applied on a non-absorbent material fastened around the trunk to minimize the potential risk of trunk burning (Anonymous 2005).

Biological control: Natural enemies include the parasitic wasp Fidiobia citri which is capable of parasitizing 50\% of each egg mass (Anonymous 2005), assassin bug (Pristhesancus plagipennis), preying mantises, parasitic nematodes (Heterorhabditis sp., Steinernema carpocapsae). The fungal pathogen, Beauveria bassiana attacks larvae while Metarhizium anisopliae attacks larvae and adults (CABI 2005).

Chemical control: Recommendations and related information on chemical management of Fuller rose beetle and other root weevils are available at:

Florida Citrus Pest Management Guide: Citrus Root Weevils (http://edis.ifas.ufl.edu/CG006)

Florida Insect Management Guide for Wood Oramental Arthropod Pests (http://edis.ifas.ufl.edu/ IG012).

\section{Selected References}

Anonymous. (1996). Rose insect pests. North Carolina Urban Integrated Pest Management: Service. http://ipm.ncsu.edu/urban/cropsci/c09w_ orn/rosepest.html (6 April 2005).

Anonymous. (2005). UC Pest Management Guidelines-Citrus: Fuller Rose Beetle. UC IPM Online. http://www.ipm.ucdavis.edu/PMG/ r107300311.html (2 March 2006).

Anonymous. (2006). Industry Advice Notice 2005/15: Citrus Exports to Japan - New and Revised Conditions (Date issued: 7 June 2005). Australian Quarantine and Inspection Service. http://www.affa. gov.au/content/output.cfm?ObjectID=77A72B26- 
C2B0-41F1-BCC6C69685F2E18A (27 February 2006).

CABI. (2005). Fuller's Rose Weevil. Crop Protection Compendium. CAB International 2005.

Chadwick CE. 1965. A review of Fuller's rose weevil (Pantomorus cervinus Boheman) (Coleoptera, Curculionidae). Journal of Entomological Society of Australia (N.S.W.) 2: 10-20.

Coats SA, McCoy CW. 1990. Fuller rose beetle (Coleoptera: Curculionidae) ovipositional preference on Florida citrus. Journal of Economic Entomology 83: 860-865.

Futch SH, McCoy Jr. CW (1993). Citrus Root Weevils. EDIS. http://edis.ifas.ufl.edu/CH050 (8 April 2005)

Haney PB, Morse JG, Arpara ML, 1988. Effect of packinghouse processing and cold storage of citrus on Fuller rose beetle egg hatch (Coleoptera: Curculionidae). Applied Agricultural Research 3: 61-64.

Johnson JA, Soderstrom EL, Brandl DG, Houck LG, Wofford PL. 1990. Gamma radiation as a quarantine treatment for Fuller rose beetle eggs (Coleoptera: Curculionidae) on citrus fruit. Journal of Economic Entomology 83: 905-909.

King JR. 1958. Occurrence, distribution and control of Fuller's rose beetle in Florida citrus groves. Proceedings of Florida State Horticultural Society 71: 146-152.

Lakin KR and Morse JG. 1989. A degree-day model for Fuller's rose beetle, Pantomorus cervinus (Boheman) (Col., Curculionidae) egg hatch. Journal of Applied Entomology 107: 102-106.

Masaki M, Kadoi M, Yoneda M. 1996. Effects of temperature on development of Fuller's rose weevil, Pantomorus cervinus (Boheman) (Coleoptera: Curculionidae). Research Bulletin of the Plant Protection Service, Japan, No. 32:7-13.

McCoy CW, Rogers ME, Futch SH, Graham JH, Duncan LW, Nigg HN. (2006). 2006 Florida Citrus Pest Management Guide: Citrus Root Weevils. EDIS. http://edis.ifas.ufl.edu/CG006 (2 March 2006).
Normark BB. 1996. Phylogeny and evolution of parthenogenetic weevils of the Aramigus tessellatus species complex (Coleoptera: Curculionidae: Naupactini): evidence from mitochondrial DNA sequences. Evolution 50: 734-745.

Woodruff RE, Bullock RC. 1979. Fuller's Rose Weevil Pantomorus cervinus (Boheman), in Florida (Coleoptera; Curculionidae). Division of Plant Industry Entomology Circulars. http://www.doacs. state.fl.us/pi/enpp/ento/entcirc/ent207.pdf (25 May 2006). 